\title{
MORPHOLOGICAL AND PHYSIOLOGICAL PLASTICITY OF SAPLINGS OF Cabralea canjerana (Vell.) MART. IN DIFFERENT LIGHT CONDITIONS ${ }^{1}$
}

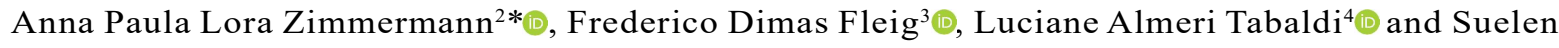
Carpenedo $\mathrm{Aimi}^{2}$ (D)

\footnotetext{
${ }^{1}$ Received on 11.06.2018 accepted for publication on 22.01.2019.

${ }^{2}$ Universidade Federal de Santa Maria, Doutora em Engenharia Florestal, Santa Maria, Rio Grande do Sul - Brasil. E-mail: <zimmermann-a@hotmail.com> and <suaimi@gmail.com>.

${ }^{3}$ Universidade Federal de Santa Maria, Departamento de Ciências Florestais, Santa Maria, Rio Grande do Sul - Brasil. Email:<dimasfleig@uol.com.br>.

${ }^{4}$ Universidade Federal de Santa Maria, Departamento de Biologia, Santa Maria, Rio Grande do Sul - Brasil. E-mail: $<$ lutabaldi@yahoo.com.br>.

*Corresponding author.
}

\begin{abstract}
This work was carried out to verify the plasticity of saplings of Cabralea canjerana plants and their capacity to adapt to different light environments by means of morphological and physiological characteristics. For this, 12 plants of a secondary Deciduous Seasonal Forest fragment were selected, six growing under canopy and six in full sun. Trees were classified according to their sociological position as emergent and dominated. The leaves were classified as apical, intermediate and basal according to their position in the canopy. The variables measured were: total number of leaves, width, length, thickness, leaf area and dry mass of leaflets; content of chlorophyll $a$ and $b$ and carotenoids. Emergent leaflets of the upper position of the canopy in full sun, which are considered the most exposed to luminosity, presented xeromorphic characteristics such as leaflet size reduction, greater limbus thickness, smaller leaf area and lower content of chlorophyll $b$. The similarity in the dry mass and pigment content demonstrates that the photosynthetic activity of the $C$. canjerana plants analyzed is not being affected by the different conditions of the environment, which demonstrates the plasticity of the species and its capacity of development in several light conditions.
\end{abstract}

Keywords: Meliaceae; Chlorophylls; Leaf attributes.

\section{PLASTICIDADE MORFOLÓGICA E FISIOLÓGICA DA ARVORE JOVENS DE CABRALEA CANJERANA (VELL.) MART EM DIFERENTES CONDIÇÕES DE LUZ}

\begin{abstract}
RESUMO - Este trabalho foi realizado com o objetivo de verificar a plasticidade dos foliolos de plantas jovens de Cabralea canjerana e sua capacidade de adaptação a diferentes ambientes luminosos por meio de características morfológicas e fisiológicas. Para isto, foram selecionadas 12 plantas de fragmento de Floresta Estacional Decidual secundário, sendo seis crescendo sob dossel e seis a pleno sol. As árvores foram classificadas conforme sua posição sociológica em emergentes e dominadas. As folhas foram classificadas em apicais, intermediárias e basais de acordo com a sua posição na copa. Foram mensuradas as variáveis número total de folhas, largura, comprimento, espessura, área foliar e massa seca dos foliolos; teor de clorofilas a e b e carotenoides. Folíolos de árvores a pleno sol, emergentes e da posição superior da copa, considerados os mais expostos a luminosidade, apresentaram características xeromórficas como redução do tamanho do foliolo, maior espessura do limbo, menor área foliar e menor teor de clorofila b. A semelhança na massa seca e no conteúdo de pigmentos evidenciam que a atividade fotossintética das plantas de C. canjerana analisadas não está sendo prejudicada pelas diferentes condições do ambiente, o que demonstra a plasticidade da espécie e sua capacidade de desenvolvimento em diversas condições de luminosidade.
\end{abstract}

Palavras-Chave: Meliaceae; Clorofilas; Atributos foliares. 


\section{INTRODUCTION}

In tropical forests, luminosity is one of the most influential factors in the process of establishment and growth of species (Lambers et al., 2008). During their life cycle, plants are exposed to different phases of high and low luminosity, mainly by the natural process of opening and closing of clearings. Thus, it is necessary that the plants possess efficient characteristics to capture the sunlight, in order to obtain advantages in the competition between species and permanence in the population (Klich, 2000).

The ability to respond adaptively to changes in environmental conditions is called phenotypic plasticity. According to Valladares et al. (2005), young plants have a higher level of plasticity when compared to adult plants, demonstrating the importance of this process in the establishment of species. The leaf is the plant organ most exposed to solar radiation, besides presenting greater plasticity, being able to acclimate quickly according to the variations in the environment.

Due to their adaptive capacity caused by exposure to solar radiation, the leaves present anatomical differences and are classified into sun leaves and shade leaves. One of these differences is the amount of layers and distribution of mesophyll cells (Yano and Terashima, 2004). There may also be variations in the concentration of photosynthetic pigments (Rego and Possamai, 2006) and maintenance and protection of the photosynthesis process (Silva et al., 2010). Thus, due to the architecture of the canopy, the morphophysiological responses of the leaves to light vary according to the different light conditions. Both sun leaves and shade leaves can be found in the same plant (Niinemets et al., 2007).

Several studies have been carried out seeking to relate the morphoanatomic characteristics of the leaves and the light intensity of the environment to which they are exposed (Pereira et al., 2013; Guerra et al., 2015). In general, sun leaves have a smaller leaf area, thicker leaves due to the greater thickness of the palisade parenchyma and greater amount of non-photosynthetic tissue, higher cuticle thickness and smaller stomata (Espíndola-Júnior et al., 2009; Sabbi et al., 2010), higher specific weight and more chloroplasts when compared to shade leaves (Lambers et al., 2008). Shade leaves have more chlorophyll per reaction center and higher content of chlorophyll $b$, as this is more effective in the interception of different wavelengths, as well as sun leaves have more chlorophyll $a$, of faster degradation to avoid photoinhibition (Taiz and Zieger, 2013).

Cabralea canjerana (Vell.) Mart (canjerana) is one of the most important tree species present in the Decidual Seasonal Forest, both for its ecological function and for its valuable wood, considered of high quality and durability (Lorenzi, 2008). Although classified by most authors as being a late secondary species, it is also classified as a pioneer species (Silva et al., 1999; Carvalho, 2002).

Therefore, this work was carried out with the objective of verifying the plasticity of saplings of canjerana and their capacity of adaptation to different light environments, through the analysis of the foliar characteristics of plants growing under canopy and in full sun.

\section{MATERIALS AND METHODS}

The study was carried out in a secondary Deciduous Seasonal Forest fragment, located in the municipality

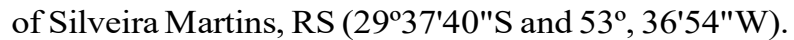
The climate of the region is of type Cfa, humid subtropical, with hot summers and average annual precipitation of $1700 \mathrm{~mm}$. However, water deficits may occur, especially in the hottest months of the year (Alvares et al., 2013). The soils are of Neosol type, shallow and visible rock outcrops. (Embrapa, 2006).

Twelve canjerana trees were randomly selected, six growing under canopy (UC) and six in an area where the release treatment was performed three years ago, by cutting competing trees from different species. Because it was a vegetation area in a secondary succession stage, the trees had an average of 4.4 meters of total height and $5.8 \mathrm{~cm}$ of diameter at $10 \mathrm{~cm}$ from the soil surface. Trees in full sun and under canopy had an average height of $5.4 \mathrm{~m}$ and $3.7 \mathrm{~m}$, and a mean diameter of $6.2 \mathrm{~cm}$ and $5.5 \mathrm{~cm}$, respectively.

Although it was considered that the trees located in the area where the release occurred were in full sun (FS), because canjerana has a grouped dispersion pattern (Zimmermann et al., 2014) some remained shaded by neighboring trees of the same species. In this way, the trees were classified as emergent (E) and dominated (D) according to their sociological position in the forest canopy and in the groups of trees of the same species. Trees that were above the height of the vegetation

Revista Árvore. 2019;43(1):e430103

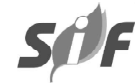


canopy in the area without release or stood out in the groups formed by only the species were considered emergent.

Besides the light condition (LC) and the sociological position (SoP), the position of leaflets in the crown was also taken into account. For this, the crown was divided into three strata, and the leaflets were classified as apical or new (A), intermediate or mature (I) and basal or old (B), according to their position in the crown. The classification was made visually in the field, taking into account coloration, thickness and presence/absence of lichens.

For analysis of width, length and thickness fifteen leaflets were randomly collected from each position of the crown. The length and width were measured with a graduated ruler in millimeters, the length being defined as the distance between the petiole-leaf blade junction and the leaf blade apex, and the width as ax ax perpendicular to the axis of the length, in the wider portion of the leaf blade.

The thickness of the leaflet was measured with an accuracy micrometer of $0.01 \mathrm{~mm}$. Leaf area analysis was performed using the WinRhizo ${ }^{\circledR}$ software, coupled to a Scanner. A sample of 20 grams of fresh leaflets was used for each position in the crown, and after that the value was extrapolated to the total fresh weight of leaves using the rule of three.

The total number of leaves per tree was counted in the Forest Management Laboratory of the Federal University of Santa Maria (UFSM). The leaflets were separated from the leaves and weighed while still wet on a precision scale. A sample of 20 grams of leaflets was separated and dried in an oven at $60^{\circ} \mathrm{C}$ until constant weight, to determine the dry mass of the leaflets. The total dry mass of the leaflets per tree was determined by extrapolation using the rule of three.

The contents of chlorophyll $a$, chlorophyll $b$ and carotenoids were determined by means of a sample of two leaflets per crown position. They were immediately packed in aluminum foil and kept in liquid nitrogen and in the Laboratory of Plant Physiology of the UFSM the samples were stored in an ultra freezer $\left(-80^{\circ} \mathrm{C}\right)$ in order to avoid the degradation of the pigments.

The leaflets were macerated in liquid nitrogen and the content of chlorophylls and carotenoids was determined from fresh samples of 0.05 grams, which were incubated at $65^{\circ} \mathrm{C}$ with dimethylsulfoxide (DMSO). The pigments were extracted and their contents estimated according to the protocol used and cited by Lima et al. (2010). The absorbances of the solutions were measured in a Clem E-205D spectrophotometer at 663 and $645 \mathrm{~nm}$ for chlorophyll $a$ and $b$, respectively, and $470 \mathrm{~nm}$ for carotenoids.

The leaflets were analyzed according to their light condition, sociological position and position in the crown. The data were submitted to the analysis of normality of residues and homogeneity of variance by the ShapiroWilk and Bartlett tests, respectively, and they were transformed by Box-Cox when they did not meet the assumptions. The t-test was used for the comparison of means between light conditions and sociological position and the Tukey's test was used for position in the crown. The analyses were performed in the statistical software SISVAR with a 5\% probability of error.

\section{RESULTS}

In general, the trees did not present high coefficients of variation for the values measured. However, a greater variation in the number of leaves $(59.7 \%)$ can be observed and consequently in the total dry mass $(53.1 \%)$ and leaf area $(47.4 \%)$, since these variables are dependent on each other (Table 1).

The leaflets of trees in full sun, emergent trees and of the apical position of the canopy were considered to be the ones that received the most luminosity. The light condition influenced the variables length and thickness of the leaflet, while the sociological position influenced the variables total number of leaves, width, length, thickness and dry mass of leaflets and leaf area. The width and length of the leaflets were also influenced by their position in the crown (Table 2).

It is noted that emerging trees invest more in leaf production than do the dominated ones. In addition, emergent trees have narrower leaflets than dominated trees, as well as apical leaflets also in relation to the leaflets of the middle and basal portions of the crown.

Leaflets of trees in full sun are about $2.4 \mathrm{~cm}$ shorter than leaflets of trees under canopy, just as emergent trees have smaller leaflets than dominated trees, which was also observed for the apical portion of the crown. Trees of $C$. canjerana in full sun have about $15 \%$ less leaf area than the trees under canopy. This reduction was expected for emergent trees, however it was not 
Table 1 - Values Observed and descriptive statistics of the morphological and physiological characteristics of the saplings of Cabralea canjerana in different light conditions, sociological positions and positions in the crown.

Tabela 1 - Valores observados e estatística descritiva das características morfológicas e fisiológicas de árvores jovens de Cabralea canjerana em diferentes condições de luz, posições sociológicas e posições da copa.

\begin{tabular}{|c|c|c|c|c|c|c|c|c|c|c|c|}
\hline $\mathrm{LC}$ & SoP & $\mathrm{PC}$ & NL & LW & LL & $\mathrm{LT}$ & LA & TDM & Clor. $a$ & Clor. $b$ & Car. \\
\hline FS & $\mathrm{D}$ & A & 9 & 3,8 & 11,8 & 25,6 & 4505,4 & 121,8 & 1,2 & 0,4 & 1,1 \\
\hline FS & $\mathrm{D}$ & I & 20 & 3,9 & 16,6 & 24,4 & 13070,7 & 279,9 & 1,2 & 0,5 & 0,9 \\
\hline FS & $\mathrm{D}$ & B & 26 & 4,1 & 16,7 & 25,3 & 12705,2 & 249,4 & 1,2 & 0,5 & 1,2 \\
\hline FS & $\mathrm{D}$ & A & 12 & 4,1 & 14,1 & 24,6 & 4803,0 & 174,6 & 1,4 & 0,7 & 0,9 \\
\hline FS & $\mathrm{D}$ & I & 22 & 4,2 & 16,5 & 25,7 & 15978,6 & 174,4 & 1,4 & 0,6 & 1,0 \\
\hline FS & $\mathrm{D}$ & B & 24 & 4,5 & 17,6 & 21,1 & 15644,5 & 156,9 & 1,3 & 0,5 & 1,2 \\
\hline FS & $\mathrm{D}$ & I & 12 & 4,8 & 19,6 & 24,2 & 11207,9 & 40,3 & 1,5 & 0,7 & 1,1 \\
\hline FS & $\mathrm{D}$ & B & 17 & 6,0 & 21,1 & 24,3 & 19250,1 & 114,7 & 1,3 & 0,5 & 1,2 \\
\hline FS & $\mathrm{E}$ & A & 74 & 3,5 & 9,1 & 30,3 & 13390,6 & 109,6 & 1,6 & 0,8 & 1,2 \\
\hline FS & $\mathrm{E}$ & I & 49 & 4,1 & 14,3 & 23,4 & 14928,5 & 25,3 & 1,4 & 0,6 & 1,3 \\
\hline FS & $\mathrm{E}$ & B & 16 & 3,6 & 15,3 & 23,5 & 5536,2 & 32,9 & 1,5 & 0,6 & 1,5 \\
\hline $\mathrm{FS}$ & $\mathrm{E}$ & A & 52 & 3,5 & 15,0 & 28,4 & 14363,8 & 102,9 & 1,0 & 0,4 & 0,8 \\
\hline FS & $\mathrm{E}$ & I & 35 & 4,3 & 14,4 & 27,1 & 24199,2 & 127,1 & 1,4 & 0,6 & 1,3 \\
\hline FS & $\mathrm{E}$ & B & 30 & 4,1 & 15,5 & 27,5 & 23567,6 & 106,9 & 1,5 & 0,6 & 1,3 \\
\hline FS & $\mathrm{E}$ & A & 33 & 3,2 & 14,5 & 29,3 & 18020,9 & 159,7 & 1,6 & 0,8 & 1,5 \\
\hline FS & $\mathrm{E}$ & I & 33 & 3,9 & 17,4 & 29,3 & 16486,5 & 128,0 & 1,1 & 0,4 & 1,2 \\
\hline FS & $\mathrm{E}$ & B & 38 & 4,0 & 16,8 & 25,0 & 18342,8 & 162,1 & 1,3 & 0,5 & 1,3 \\
\hline FS & $\mathrm{D}$ & A & 14 & 4,3 & 22,5 & 24,9 & 11017,0 & 48,6 & 1,7 & 1,0 & 1,6 \\
\hline UC & $\mathrm{D}$ & A & 23 & 3,8 & 18,6 & 16,3 & 9900,2 & 127,0 & 1,4 & 0,6 & 1,2 \\
\hline UC & $\mathrm{D}$ & I & 15 & 4,7 & 19,8 & 13,3 & 10180,3 & 72,9 & 1,7 & 1,0 & 1,6 \\
\hline UC & $\mathrm{D}$ & B & 17 & 5,7 & 22,8 & 13,5 & 16645,9 & 94,2 & 1,4 & 0,7 & 1,4 \\
\hline UC & $\mathrm{D}$ & A & 8 & 4,3 & 19,5 & 16,7 & 5382,9 & 48,7 & 1,3 & 0,5 & 1,2 \\
\hline UC & $\mathrm{D}$ & I & 9 & 4,8 & 23,0 & 16,3 & 10413,0 & 233,8 & 1,7 & 0,9 & 1,6 \\
\hline UC & $\mathrm{D}$ & B & 20 & 5,4 & 21,7 & 15,6 & 16055,4 & 110,3 & 1,2 & 0,5 & 1,3 \\
\hline UC & $\mathrm{D}$ & A & 27 & 4,1 & 17,9 & 18,2 & 16094,0 & 77,6 & 1,4 & 0,6 & 1,2 \\
\hline UC & $\mathrm{D}$ & I & 21 & 4,8 & 20,8 & 17,1 & 17528,4 & 71,5 & 1,7 & 1,0 & 1,6 \\
\hline UC & $\mathrm{D}$ & B & 20 & 4,6 & 18,2 & 18,6 & 4994,0 & 113,8 & 1,7 & 1,0 & 1,6 \\
\hline UC & $\mathrm{E}$ & A & 51 & 3,9 & 16,3 & 18,3 & 20538,9 & 113,9 & 1,3 & 0,4 & 1,1 \\
\hline UC & $\mathrm{E}$ & I & 16 & 4,1 & 17,7 & 17,4 & 13530,0 & 117,9 & 1,3 & 0,6 & 1,2 \\
\hline UC & $\mathrm{E}$ & B & 21 & 4,4 & 17,3 & 18,5 & 14005,6 & 42,2 & 1,6 & 0,8 & 1,2 \\
\hline UC & $\mathrm{E}$ & A & 22 & 3,0 & 15,0 & 16,8 & 5273,4 & 47,4 & 1,2 & 0,5 & 1,1 \\
\hline $\mathrm{UC}$ & $\mathrm{E}$ & I & 53 & 3,6 & 15,6 & 15,4 & 29577,0 & 89,9 & 0,9 & 0,3 & 0,8 \\
\hline UC & $\mathrm{E}$ & B & 31 & 3,6 & 19,1 & 15,5 & 15306,5 & 130,0 & 1,6 & 0,8 & 1,2 \\
\hline $\mathrm{UC}$ & $\mathrm{E}$ & A & 74 & 3,3 & 14,8 & 18,1 & 30522,8 & 224,4 & 0,7 & 0,2 & 0,7 \\
\hline UC & $\mathrm{E}$ & I & 55 & 4,3 & 17,4 & 18,6 & 32992,1 & 252,4 & 1,5 & 0,7 & 1,4 \\
\hline UC & $\mathrm{E}$ & B & 41 & 3,7 & 17,7 & 18,1 & 26270,3 & 199,6 & 1,6 & 0,8 & 1,6 \\
\hline \multicolumn{3}{|c|}{ Mean } & 28,9 & 4,2 & 17,3 & 21,3 & 15339,7 & 124,5 & 1,4 & 0,6 & 1,2 \\
\hline \multicolumn{3}{|c|}{ CV\% } & 59,7 & 15,6 & 17,5 & 23,4 & 47,4 & 53,1 & 17,1 & 31,7 & 19,2 \\
\hline
\end{tabular}

Where: LC: light condition; SoP: Sociological Position; PC: Position in the Crown; E: Emergent; D: Dominated; FS: Full Sun; UC: Under Canopy; A: Apical Leaflets; I: Intermediate Leaflets; B: Basal Leaflets; NL: Number of Leaves; LW: Leaflet Width (cm); LL: Leaflet Length $(\mathrm{cm})$; LA: Leaf Area $\left(\mathrm{cm}^{2}\right)$; LT: Leaflet Thickness $(\mathrm{mm})$; TDM: Total Dry Mass of Leaflets $(\mathrm{g})$; Clor. $a$ : Content of Chlorophyll a (mg g $\left.\mathrm{MF}^{-1}\right)$; Clor. $b$ : Content of Chlorophyll $\mathrm{b}\left(\mathrm{mg} \mathrm{g} \mathrm{MF}^{-1}\right)$; Car.: Content of Caratenoids $\left(\mathrm{mg} \mathrm{g} \mathrm{MF}^{-1}\right)$; CV\%: Coefficient of Variation in percentage

verified because the trees in this position had a higher total number of leaves.

The leaflets of $C$. canjerana trees in full sun presented a leaf blade thickness about $53 \%$ greater in relation to the thickness of the shade leaflets. The thicker leaflets were also found in the emergent trees and in the apical position of the crown.
The total dry mass of the leaflets was similar for the light conditions and position of the leaflets in the crown, evidencing that regardless of the level of luminosity to which the crowns are exposed, the trees are accumulating phytomass in the shoot part for similar reasons. However, there was a difference for this variable in relation to the sociological position of the plants, which was already expected, since the leaf area of

Revista Árvore. 2019;43(1):e430103 
Table 2 - Means of morphological and physiological characteristics of Cabralea canjerana leaflets, under different light conditions, sociological position and position in the crown.

Tabela 2 - Médias das características morfológicas e fisiológicas dos foliolos de Cabralea canjerana, sob diferentes condições de luz, posições sociológicas e posições da copa.

\begin{tabular}{ccccccccccc}
\hline Fator & Tret & NL & LW & LL & LT & LA & TDM & Clor. $a$ & Clor. $b$ & Car. \\
\hline \multirow{2}{*}{ LC } & FS & $* 86,0 \mathrm{a}$ & $4,1 \mathrm{a}$ & $16,0 \mathrm{~b}$ & $25,8 \mathrm{a}$ & $* 42836,4 \mathrm{a}$ & $* 128,6 \mathrm{a}$ & $1,36 \mathrm{a}$ & $0,59 \mathrm{a}$ & $1,20 \mathrm{a}$ \\
& $\mathrm{UC}$ & $* 87,0 \mathrm{a}$ & $4,2 \mathrm{a}$ & $18,5 \mathrm{a}$ & $16,8 \mathrm{~b}$ & $* 49201,8 \mathrm{a}$ & $* 120,4 \mathrm{a}$ & $1,40 \mathrm{a}$ & $0,67 \mathrm{a}$ & $1,27 \mathrm{a}$ \\
\hline \multirow{2}{*}{ SoP } & $\mathrm{E}$ & $* 127,0 \mathrm{a}$ & $3,8 \mathrm{a}$ & $15,7 \mathrm{~b}$ & $23,1 \mathrm{a}$ & $* 57755,7 \mathrm{a}$ & $* 154,9 \mathrm{a}$ & $1,34 \mathrm{a}$ & $1,58 \mathrm{a}$ & $1,21 \mathrm{a}$ \\
& $\mathrm{D}$ & $* 58,0 \mathrm{~b}$ & $4,6 \mathrm{~b}$ & $18,8 \mathrm{a}$ & $20,0 \mathrm{a}$ & $* 37635,8 \mathrm{~b}$ & $* 81,9 \mathrm{~b}$ & $1,43 \mathrm{a}$ & $1,67 \mathrm{a}$ & $1,26 \mathrm{a}$ \\
\hline \multirow{2}{*}{ PC } & $\mathrm{A}$ & $33,0 \mathrm{a}$ & $3,7 \mathrm{~b}$ & $15,8 \mathrm{a}$ & $22,3 \mathrm{~b}$ & $12817,7 \mathrm{a}$ & $104,7 \mathrm{a}$ & $1,32 \mathrm{a}$ & $0,58 \mathrm{a}$ & $1,13 \mathrm{a}$ \\
& $\mathrm{I}$ & $28,0 \mathrm{a}$ & $4,3 \mathrm{a}$ & $17,8 \mathrm{~b}$ & $21,0 \mathrm{a}$ & $17507,7 \mathrm{a}$ & $142,4 \mathrm{a}$ & $1,40 \mathrm{a}$ & $0,66 \mathrm{a}$ & $1,25 \mathrm{a}$ \\
& $\mathrm{B}$ & $25,0 \mathrm{a}$ & $4,5 \mathrm{a}$ & $18,3 \mathrm{~b}$ & $20,5 \mathrm{a}$ & $15693,7 \mathrm{a}$ & $126,4 \mathrm{a}$ & $1,43 \mathrm{a}$ & $0,65 \mathrm{a}$ & $1,33 \mathrm{a}$ \\
\hline
\end{tabular}

Where: LC: Light Condition; SoP: Sociological Position; PC: Position in the Crown; Trat: Treatment; FS: Full Sun; UC: Under Canopy; E: Emergent; D: Dominadas; A: Apical Leaflets; I: Intermediate Leaflets; B: Basal Leaflets; NL: Number of Leaves; LW: Leaflet Width $(\mathrm{cm})$; L: Leaflet Length $(\mathrm{cm})$; LT: Leaflet Thickness $(\mathrm{mm})$; LA: Leaf Area $\left(\mathrm{cm}^{2}\right)$; TDM: Total Dry Mass of Leaflets $(\mathrm{g})$; Clor. $a$ : Content of Chlorophyll a $\left(\mathrm{mg} \mathrm{g} \mathrm{MF}^{-1}\right)$; Clor. $b$ : Content of Chlorophyll b ( $\left.\mathrm{mg} \mathrm{g} \mathrm{MF}^{-1}\right)$; Car.: Content of Carotenoids (mg g MF $\left.{ }^{-1}\right)$. Means followed by the same letter do not differ statistically at $5 \%$ probability of error by the T test (LC and SoP) or the Tukey's test (PC); *: total value referring to the sum of the values of the three positions in the crown.

emergent and dominated trees also showed significant differences.

Even without statistical difference, it can be observed that trees in full sun presented a lower value of chlorophyll $a$ in relation to the trees under canopy, as well as the emergent ones in relation to the dominated ones and the leaflets of the apical region in relation to the other positions of the crown. In relation to chlorophyll $b$, leaflets of trees under canopy, dominated and of the lower regions of the crown, considered more shaded in relation to the other conditions, presented higher values of the pigment. The carotenoid contents were higher in the leaflets of trees under canopy, dominated and in the basal portion of the canopy.

\section{DISCUSSION}

The greater number of leaves in emergent trees of $C$. canjerana in relation to the dominated ones may have direct relation with the production and use of photoassimilates. This seems to be a strategy of the species to maintain its rate of growth in conditions of greater luminosity. According to Sabbi et al. (2010), leaves more exposed to light tend to have xeromorphic characteristics, such as the reduction of leaf area and, to compensate for the reduction in the rate of photosynthesizers, some species may present a larger number of leaves.

The values found for the width of the leaflet are in accordance with Carvalho (2002), who described that the leaflets of the canjerana vary between 3 to
$5 \mathrm{~cm}$ of width. Pinheiro et al. (1989) analyzing seedlings of the species found leaflets with width between 1 and $5 \mathrm{~cm}$, demonstrating that the upper limit of this variable remains constant as the plant ages.

Similar means in width of leaflets of trees growing in full sun and under canopy were also observed by Guerra et al. (2015) in their work with Handroanthus chrysotrichus. As found in this study, the authors also verified the influence of light environments only on the length of the leaflet, demonstrating that the plasticity presented by some species occurs from the variation of the length and not the width of the leaflet.

The smaller size of the leaflets of emergent trees and of the apical portion of the crown can be explained by the need of a decrease in its leaf area due to greater exposure of the crown to light. This may be one of the photoprotective mechanisms required to prevent photoinhibition under high light conditions. Pires et al. (2015), divided the crown of Schinus molle in three strata and verified that the leaves placed in the upper stratum of the crown are smaller in relation to the leaves of the other positions and also consider these results a strategy to decrease the transpiration rate.

The reduction in the size of the leaflets can be interpreted as an adaptive strategy of the species to the greater light exposure, because in this environment, species tend to reduce their leaves in order to avoid overheating, decrease transpiration rate (Klich, 2000) and protect the photosynthetic tissues from excess radiation.

The reduction of leaf area in trees exposed to higher solar radiation is seen as a strategy to avoid damages 
to the photosynthetic apparatus and photoinhibition due to excess light. On the other hand, the increase of leaf area in shaded plants is seen as a way for the plant to compensate for the smaller amount of light received, maximizing the absorption and use of light in physiological processes of growth and increasing the area of capture of light rays (Espíndola-Júnior, 2006). Similar results were found in studies by EspindolaJúnior et al. (2009) and Sabbi et al. (2010).

According to Yano and Terashima (2004), the greater thickness of the sun leaves is due to the fact that the light stimulates the development of the palisade parenchyma. The thickening of the palisade parenchyma also presents advantages such as the greater absorption of $\mathrm{CO}_{2}$ and decrease in leaf heating, facilitating the cooling and maintaining the internal temperature of the leaf favorable for the physiological processes (Terashima et al., 2006; Taiz and Zieger, 2013).

In addition, the elongation of cells of the palisade and spongy parenchyma is seen as a strategy to decrease the amount and vigor of light reaching the chlorophyll parenchyma. The luminous intensity decreases as it crosses the leaf since it is reflected by the cell walls and the intercellular spaces. Thus, while sun leaves have greater thickness of the palisade parenchyma; due to the low amount of light they receive, the shaded leaves have only one layer of it, in order to allow a greater amount of light to reach the chlorophyllic parenchyma (Lambers et al., 2008).

Because they are in the upper part of the crown, the apical leaflets have xeromorphic characteristics similar to the sun leaves, since there is a greater interception of solar radiation in this portion of the crown than in the other portions. Similarly, Pires et al. (2015), analyzing the anatomical characteristics of leaflets of $S$. molle found greater thickness of the mesophyll in the leaves positioned in the higher parts of the canopies.

According to Taiz and Zieger (2013), the determination of the dry mass of the shoot or of its parts can be used for growth analysis. This is because the relative growth rate of plants depends on the phytomass accumulated from the photosynthetic process. Thus, the photosynthetic rate is directly linked to the net assimilation rate of the biomass, by the gain and loss of carbon, through photosynthesis and respiration, respectively (James and Rebecca, 2007).
According to Castoldi et al. (2009), as well as the ontogeny, the rate of accumulation of organic matter depends on the amount of radiation intercepted by the leaves, the internal conditions of the plant, the leaf index and the efficiency with which the plant converts this energy into photoassimilates. Thus, it can be said that the modifications in the leaflets seem to be being effective in maintaining the productive rate of the species in the different light conditions. These results demonstrate that the $C$. canjerana plants analyzed were able to adjust their photosynthesizing apparatus to the different light conditions, since they are accumulating dry mass in the same proportion.

The lower content of chlorophyll $a$ in the leaflets of emergent trees and of the apical region of the crown shows that the exposure of leaflets of the this species to the greater luminosity decreases the content of this pigment. As for chlorophyll $b$, higher levels are expected in shaded environments, since it aids in the absorption of light, capturing other wavelengths other than chlorophyll $a$ and transferring them to the reaction centers (Taiz and Zieger, 2013). This contributes to the acclimatization of $C$. canjerana to less light availability, since chlorophyll $b$ is the main component of the LHC protein (Koike et al., 2001), which acts as a complex antenna in the transfer of energy to the reaction center of photosystem II (Lam et al., 1984). Low content of chlorophyll $b$ in leaves in full sun facilitates the photoprotection of the reaction center of photosystem II by reducing light absorption (Walters, 2005).

Carotenoids are a group of accessory pigments capable of performing various functions in the process of photosynthesis. They are responsible for helping to capture light from different wavelengths and to transfer it to chlorophyll $a$, responsible for performing the photochemical phase (Taiz and Zieger, 2013). However, its main role is photoprotective action, preventing the photosynthetic apparatus from oxidative damage (Kurz, 2008). It was expected, therefore, that the leaflets under higher light conditions would present higher levels of this pigment, which was not verified, showing that even though it is considered to be a tolerant species, the exposure of the plants to full sun did not produce sufficient effects to cause oxidative stress (Munns and Tester, 2008) and showing the adaptation of the photosynthetic apparatus of the species to the different light conditions analyzed.

Revista Árvore. 2019;43(1):e430103 


\section{CONCLUSION}

The leaflets of $C$. canjerana have morphological and physiological plasticity when exposed to different light environments. The leaflets of trees in full sun, emergent and of the upper position of the crown, presented xeromorphic characteristics as reduction in leaflet size, smaller leaf area, greater thickness and lower content of chlorophyll $b$.

The plasticity of the species is of fundamental importance to its silviculture, since it demonstrates the possibility of cultivation under different intensities of light.

\section{REFERENCES}

Alvares CA, Stape JL, Sentelhas PC, Moraes Gonçalves JL, Sparovek G. Köppen's climate classification map for Brazil. Meteorologische Zeitschrift. 2013;22(6):711-28.

Carvalho PER. Canjarana, taxonomia. Colombo: Ministério da Agricultura, Pecuária e Abastecimento; 2002. (Circular técnica, 67)

Castoldi R, O Charlo HC, Vargas PF, Braz LT. Crescimento, acúmulo de nutrientes e produtividade da cultura da couve-flor. Horticultura Brasileira. 2009;27(4):438-46.

Pereira JD, Pimenta JÁ, Medri ME, Moreira RS. avaliações morfológicas e micromorfométricas de folhas de sol e de sombra de Lithraea molleoides (Vell.) Engl. (Anacardiaceae). Evolução e

Conservação da Biodiversidade. 2013;4(1):22-31.

Empresa Brasileira de Pesquisa Agropecuária Embrapa. Centro Nacional de Pesquisa de Solos. Sistema brasileiro de classificação de solos. Rio de Janeiro: 2006.

Espíndola Júnior A. Morfologia e anatomia foliar de duas espécies medicinais (Mikania glomerata Spreng. - Asteraceae e Bauhinia forfi cata Link. - Leguminosae) associadas à erva mate, sob diferentes condições de luminosidade [dissertação]. Curitiba: Universidade Federal do Paraná; 2006.

Espíndola Júnior A, Boeger MRT, Maccari Júnior A, Reissmann CB, Rickli FL. Variação na estrutura foliar de Mikania glomerata Spreng. (Asteraceae) sob diferentes condições de luminosidade. Revista Brasileira de Botânica. 2009;32(4):749-58.

Guerra A, Gonçalves LG, Santos LS, Medri C. Morfoanatomia de folhas de sol e de sombra de Handroanthus chrysotrichus (MART. EX DC.) Mattos (BIGNONIACEAE). SaBios: Revista da Saúde e Biologia. 2015;10(1):60-71.

James JJ, Rebecca ED. A basis for relative growth rate differences between native and invasive forb seedlings. Rangeland Ecology \& Management. 2007;60:395-400.

Klich MG. Leaf variations in Elaeagnus angustifolia related to environmental heterogeneity. Environmental and Experimental Botany. 2000;44:171-83.

Koike T, Kitao M, Maruyama Y, Mori S, Lei TT. Leaf morphology and photosynthetic adjustments among deciduous broad-leaved trees within the vertical canopy profile. Tree Physiology. 2001;21(12-13):951-8.

Kurz C, Carle R, Schieber A. HPLC-DAD MSn characterisation of carotenoids from apricots and pumpkins for the evaluation of fruit product authenticity. Food Chemistry. 2008;110:522-30.

Lam E, Oritz W, Mayfield S, Malkin R. Isolation and characterization of a light-harvesting chlorophyll a/b protein complex associated with photosystem I. Plant Physiology. 1984;74(3):650-5.

Lambers H, Chapim FS, Pons TL. Plant physiological ecology. $2^{\text {nd }}$.ed. Berlin: Springer; 2008.

Lorenzi H. Árvores brasileiras: manual de identificação e cultivo de plantas arbóreas do Brasil. $5^{\mathrm{a}}$.ed. São Paulo: Nova Odessa; 2008. v.1

Munns R, Tester M. Mechanisms of salinity tolerance. Annual Review of Plant Biology. 2008;59:651-81.

Niinemets U, Lukjanova A, Turnbull MH, Sparrow AD. Plasticity in mesophyll volume fraction modulares light-aclimation in needle photosynthesis in two pines. Tree Physiology. 2007;27(8):1137-51. 
Pinheiro AL, Ramalho RS, Vidal WN, Vidal MRR. Dendrological studies aimed at natural regeneration of Meliaceae in the microregion of Viçosa. I. Identification and description of the ten species. Revista Árvore. 1989;13(1):51-66.

Pires MF, Pereira MP, Castro EM, Barbosa S, Pereira FJ. Micromorfometria foliar de Schinus molle L. (Anarcadiaceae) em diferentes alturas na copa. Cerne. 2015;21(1):17-25.

Rego GM, Possamai E. Efeito do sombreamento sobre o teor de clorofila e crescimento inicial do Jequitibá-Rosa. Boletim de Pesquisa Florestal. 2006;53:179-94.

Sabbi LBC, Ângelo AC, Boeger MR. Influência da luminosidade nos aspectos morfoanatômicos e fisiológicos de folhas de Schinus terebinthifolius Raddi (Anacardiaceae) implantadas em duas áreas com diferentes graus de sucessão, nas margens do Reservatório Iraí, Paraná, Brasil. Iheringia, Série Botânica. 2010;65(2):171-81.

Silva EN, Ribeiro RV, Silva SLF, Viégas RA, Silveira JAG. Comparative effects of salinity and water stress on photosynthesis, water relations and growth of Jatropha curcas plants. Journal of Arid Environments. 2010;74(10):1130-7.

Silva JCS, Salgado MAS, Felfili JM, Rezende AV, Franco AC. Desenvolvimento inicial de Cabralea canjerana em diferentes condições de luz. Boletim do Herbário Ezechias Paulo Heringer, 1999;4:80-89, 1999.

Taiz L, Zeiger E. Fisiologia vegetal. $5^{\text {a }}$ ed. Porto Alegre: Artmed; 2013.

Terashima I, Hanba YT, Tazoe Y, Vyas P, Yano S. Irradiance and phenotype: comparative ecodevelopment of sun and shade leaves in relation to photosynthetic $\mathrm{CO} 2$ diffusion. Journal of Experimental Botany. 2006;57(2):343-54.

Valladares F, Arrieta S, Aranda I, Lorenzo D, Sánchez-Gómez D, Tena D, et al. Shade tolerance, photoinhibition sensitivity and phenotypic plasticity of Ilex aquifolium in continental Mediterranean sites. Tree Physiology. 2005;25(8):1041-52.

Zimmermann APL, Lira DFS, Fleig FD. Estrutura e distribuição espacial da regeneração natural de canjerana em Floresta Estacional Decidual. Pesquisa Florestal Brasileira. 2014;34(80):369-73.

Yano S, Terashima I. Developmental process of sun and shade leaves in Chenopodium album L. Plant, Cell and Environment. 2004;27:781-93.

Walters RG. Towards an understanding of photosynthetic acclimation. Journal of Experimental Botany. 2005;56:435-47. 